\title{
PENTAQUINE (SN-13,276), A THERAPEUTIC AGENT EFFECTIVE IN REDUCING THE RELAPSE RATE IN VIVAX MALARIA ${ }^{1}$
}

\author{
By ALF S. ALVING, BRANCH CRAIGE, JR.,2 RALPH JONES, JR.,2 C. MERRILL \\ WHORTON, ${ }^{2}$ THEODORE N. PULLMAN, 2 AND LILLIAN EICHELBERGER
}

(From the Malarial Research Unit, Department of Medicine, University of Chicago)

(Received for publication January 4, 1947)

\section{INTRODUCTION}

Pentaquine, SN-13,276, has been found to be one of the most promising members thus far studied of a series of antimalarial drugs related to pamaquin. It has the property, also possessed by toxic doses of pamaquin (plasmochin), of eradicating vivax infections, accomplishing this with doses which produce only mild reactions in most individuals. This paper describes the therapeutic trials upon which these conclusions are founded.

Pentaquine, (5-isopropylaminoamylamino)-6methoxy-quinoline, differs constitutionally from pamaquin in the structure of the aliphatic side chain in the 8-position (Figure 1). The drug was supplied ${ }^{3}$ and used in the form of the monophosphate salt which is 75.5 per cent base. All dosages recorded in this paper are in terms of the base

\footnotetext{
1 This investigation was carried out under contract, recommended by the Committee on Medical Research, between the Office of Scientific Research and Development and the University of Chicago. This work was further aided by the participation of Army Modical officers assigned to the project by the Surgeon General, U. S. Army.

Through a cooperative arrangement between Professor Clay G. Huff and Dr. Frederick Coulston, Department of Bacteriology and Parasitology, and the Malarial Research Unit, Department of Medicine, the former group bred Anopheles quadrimaculatus mosquitoes, supervised their infection and the inoculation of volunteers, and determined the intensity of infection in the salivary glands of the mosquitoes. The latter group assumed the responsibility for clinical care of patients studied by both groups.

The authors express their thanks to the Malaria Study Section of the National Institute of Health for editorial assistance and for arrangements in regard to the publication of this paper. They are also grateful to the Abbott Laboratories, E. I. du Pont de Nemours and Company, Inc., E. R. Squibb and Sons, Eli Lilly and Company, Sharp and Dohme, Inc., and Wyeth, Inc., for contributing toward the publication costs.

2 Captain, M.C., A.U.S.

3 Pentaquine was synthesized by Dr. Nathan Drake, Department of Chemistry, University of Maryland.
}

weight in order to facilitate comparison with pamaquin.

In the experimental animals, the antimalarial effect of pentaquine, its pharmacology and toxicology have been investigated $(1,2)$. Activity, 80 to 128 times that of quinine and two to eight times that of pamaquin in avian malaria, first focused attention on this compound.

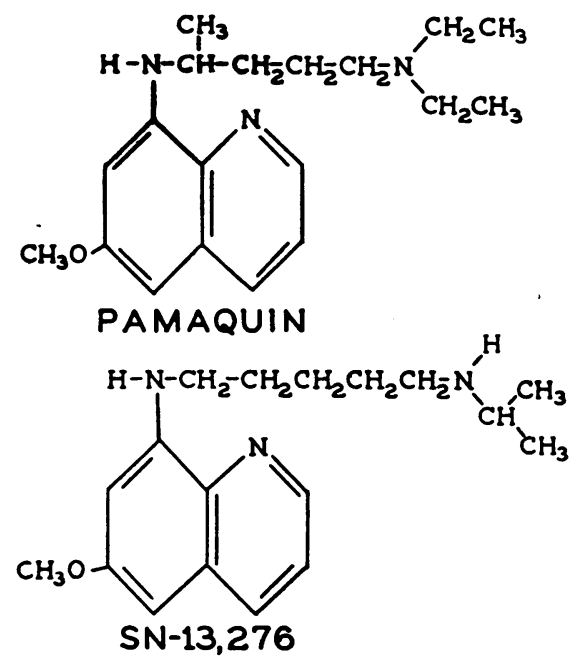

Fig. 1. Pentaquine (SN-13,276) and Pamaquin (Plasmochin) are 6-Methoxy-8-Aminoquinolines Differing Only in the Structure of the Aliphatic Side Chain in the 8-Position

In mammals it is rapidly absorbed from the gastro-intestinal tract. Maximum plasma levels usually proportional to the dose are attained in one and a half to two hours, little or none remaining after six or eight hours. Tissue storage apparently does not occur, and urinary excretion is negligible. Disappearance of the drug is probably due to rapid degradation in the animal body. In mammals its physiological disposition, therefore, is similar to that of pamaquin, the only difference being that plasma concentrations are sustained longer with pentaquine. 
With certain exceptions the toxicity of pentaquine in experimental animals is similar qualitatively to that of pamaquin. In acute, and in shortterm chronic toxicity studies, pentaquine was from one-fourth to one-half as toxic as pamaquin. In the dog, pamaquin in large doses produces severe anorexia, emaciation and ocular paralysis due to central impairment of the sympathetic innervation of the eye. In high dosages pamaquin produces leukopenia, neutropenia, anemia, methemoglobinemia, emaciation, depression, and liver damage in the monkey, effects which are not produced with pentaquine in this species. On the other hand, in both dog and monkey an ill-defined deleterious effect on the heart and circulation appears to be more severe with toxic doses of pentaquine than with pamaquin.

The concurrent administration of quinine increases the severity of the toxicity of pentaquine in both the rat and monkey but does not alter the toxicity qualitatively. In this respect, pentaquine behaves like pamaquin in the experimental animal.

\section{PROCEDURES AND METHODS}

Details of the drug-testing procedures are reported elsewhere (3). In brief, healthy white inmate volunteers ${ }^{4}$ at the Illinois State Penitentiary were inoculated with Southwest Pacific (Chesson) vivax malaria by the bites of infected mosquitoes. Uniformity of the disease was sought by the use of presumably susceptible individuals in primary attacks or first or second relapses, after inoculation with the bites of ten mosquitoes whose infectivity was verified by dissection. None of the subjects had had prolonged suppressive treatment, and therapy with test drugs was begun early in the clinical attack. Accidental reinfection was not a problem because the penitentiary was in a non-endemic area.

In spite of these efforts to secure uniformity in the induced disease, variation became apparent. It was possible, however, to divide the more severely from the less severely infected on the basis of the length of the prepatent and preceding latent periods (4). The less severely infected subjects, who had long prepatent or latent periods, were characterized by a relapse rate of 67 per cent after treatment with so-called suppressive drugs, while the more severely infected subjects had a relapse rate of 98 per cent. A small third group of volunteers had massive infections, being inoculated by the bites of 80 infected mosquitoes, instead of the ten used in the standard procedure, or by the intracutaneous injection of

4 The studies reported in this paper would not have been possible except for the enthusiastic cooperation of the inmate volunteers and administrative officials of Stateville Penitentiary. the dissected salivary glands of 45 to 75 infected mosquitoes. The relapse rate of this group was 100 per cent after treatment with suppressive drugs. The subjects accordingly were divided into three categories representing (1) a moderate, (2) a severe, and (3) an extraordinarily severe challenge to the therapeutic efficacy of the test drug. Pentaquine was administered to 82 subjects in doses of $60 \mathrm{mgm}$. of base or less, daily. An additional group of 17 subjects without clinical malaria, treated during latency, were included in toxicity studies. A total of 99 subjects are accordingly available for this report.

The patients were hospitalized during treatment but were allowed to be up ad libitum. Symptoms were elicited daily or oftener, evidence of toxicity was collected, and the effect on the disease evaluated by following the fever and parasitemia. Blood films for parasite counts were made daily during the clinical disease and every two days thereafter until relapse occurred. If no relapse occurred in six months, films were then made once weekly. Some of the subjects received quinine or paludrine concurrently with pentaquine. All drugs were given in oral doses every four hours for 14 days, treatment being started after the subject had been febrile for one day and had had parasitemia for two.

The concentration of pentaquine in the plasma was estimated every other day using the modified method (5) of Brodie, Udenfriend and Taggart (6).

The amounts of methemoglobin and hemoglobin were determined daily on venous blood by the photocolorimetric method of Wendel (7).

\section{RESULTS}

\section{Therapeutic effect}

Suppression of fever and parasitemia. When administered alone in doses of 30 or $60 \mathrm{mgm}$. of base a day, pentaquine resulted in the disappearance of fever in two to four days and' of parasitemia in three to six (Table I). Its effect in this respect was not significantly different from the effect of quinine alone or of quinine and pentaquine administered concurrently.

Radical cure. Twenty-six moderately infected subjects received $60 \mathrm{mgm}$. of the base daily and four others similarly infected received 30 to 45 mgm. In these 30 subjects, quinine was concurrently administered. Only one suffered a relapse. The relapse rate of 3 per cent thus obtained may be compared to the 67 per cent obtained when similar subjects were treated with suppressive drugs (Table I).

Of 21 volunteers with severe infections treated with or without quinine at doses of pentaquine ranging from 15 to $45 \mathrm{mgm}$. of the base a day, 20 
TABLE I

Therapeutic effect of pentaquine administered for 14 days in mosquito-induced vivax malaria (Chesson)

\begin{tabular}{|c|c|c|c|c|c|c|c|c|c|c|c|c|}
\hline \multirow{2}{*}{$\begin{array}{l}\text { Daily } \\
\text { dosage } \\
\text { (base) }\end{array}$} & \multirow{2}{*}{$\begin{array}{l}\text { No. } \\
\text { of } \\
\text { sub- } \\
\text { jects }\end{array}$} & \multicolumn{2}{|c|}{$\begin{array}{l}\text { Mean concentration } \\
\text { of drug in plasma }\end{array}$} & \multicolumn{2}{|c|}{$\begin{array}{c}\text { First } \\
\text { afebrile } \\
\text { day }\end{array}$} & \multicolumn{2}{|c|}{$\begin{array}{c}\text { First day } \\
\text { without } \\
\text { parasitemia }\end{array}$} & \multicolumn{3}{|c|}{$\begin{array}{l}\text { Relapse ratio } \\
\text { individuals relapsed/ } \\
\text { individuals treated }\end{array}$} & \multirow{2}{*}{$\begin{array}{c}\text { Duration of } \\
\text { subsequent } \\
\text { latent period } \\
\text { in subjects } \\
\text { who relapsed }\end{array}$} & \multirow{2}{*}{$\begin{array}{c}\text { Duration of } \\
\text { follow-up } \\
\text { period in } \\
\text { subjects who } \\
\text { did not relapse }\end{array}$} \\
\hline & & Range & Mean & Range & Mean & Range & Mean & $\begin{array}{l}\text { Mod- } \\
\text { erate } \\
\text { infec- } \\
\text { tion }\end{array}$ & \begin{tabular}{|c} 
Severe \\
infec- \\
tion
\end{tabular} & $\begin{array}{l}\text { Mase- } \\
\text { inee } \\
\text { infec- } \\
\text { tion }\end{array}$ & & \\
\hline $\begin{array}{c}\text { mgm. } \\
15 \\
\text { with } \\
\text { quinine }\end{array}$ & $\begin{array}{r}\text { no. } \\
5\end{array}$ & $\begin{array}{c}\text { gammall. } \\
30-51\end{array}$ & $\begin{array}{c}\text { gamma/l. } \\
40\end{array}$ & $\begin{array}{l}d a y \\
2-3\end{array}$ & $\begin{array}{l}d a y \\
2.6\end{array}$ & $\begin{array}{l}d a y \\
3-4\end{array}$ & $\begin{array}{l}d a y \\
3.6\end{array}$ & & $5 / 5$ & & $\begin{array}{r}\text { days } \\
9,12,15 \\
21,37\end{array}$ & \\
\hline 30 & 5 & $25-48$ & 34 & $2-4$ & 2.6 & $4-6$ & 4.6 & & $5 / 5$ & & $3,4,4,9,40$ & \\
\hline $\begin{array}{c}30 \\
\text { with } \\
\text { quinine }\end{array}$ & 10 & $12-67$ & 44 & $1-3$ & 1.9 & $3-5$ & 4.1 & $0 / 1$ & $8 / 9$ & & $\begin{array}{l}11,12,17 \\
38,41,41 \\
48,64\end{array}$ & 6 months \\
\hline $\begin{array}{c}45 \\
\text { with } \\
\text { quinine }\end{array}$ & 5 & $24-58$ & 43 & 2 & 2.0 & $3-5$ & 4.0 & $0 / 3$ & $2 / 2$ & & 14,15 & \\
\hline 60 & 5 & $29-49$ & 41 & $2-4$ & 2.8 & $3-5$ & 4.0 & & $2 / 4$ & $1 / 1$ & 12,$128 ; 17$ & 9 months \\
\hline $\begin{array}{c}60 \\
\text { with } \\
\text { paludrine }\end{array}$ & 5 & $139-452$ & 270 & $1-4$ & 2.4 & $4-7$ & 4.8 & & $4 / 5$ & & $\begin{array}{l}24,29,36 \\
120\end{array}$ & 4 months \\
\hline $\begin{array}{c}60 \\
\text { with } \\
\text { quinine }\end{array}$ & 47 & 26-196 & 63 & $0-4$ & 2.0 & $1-6$ & 3.6 & $1 / 26$ & $3 / 17$ & $4 / 4$ & $\begin{array}{l}22,45,54,70 \\
19,43,44 \\
87\end{array}$ & $\begin{array}{c}\text { See notes } \\
\text { below }\end{array}$ \\
\hline $\begin{array}{l}\text { Controls } \\
\text { Quinine } \\
\text {. alone }\end{array}$ & 13 & & & $1-4$ & 2.3 & $4-6$ & 4.7 & $4 / 5$ & $6 / 6$ & $2 / 2$ & $\begin{array}{l}10,15,25 \\
221 ; 7,8 \\
10,11,11 \\
12 ; 9,10\end{array}$ & 12 months \\
\hline $\begin{array}{l}\text { Other } \\
\text { suppressive } \\
\text { drugs }\end{array}$ & 80 & & & & & & & $8 / 12$ & $44 / 45$ & $4 / 4$ & & 4-15 months \\
\hline
\end{tabular}

The dosages of pentaquine are in terms of the base. Quinine was administered in doses of 2.0 grams of the sulphate daily and paludrine in doses of 1.0 gram of the base daily. Drugs were administered on a four-hour schedule. The plasma concentrations are the average of seven estimations for each patient; blood for plasma analyses was collected about one hour after the $8 \mathrm{a} . \mathrm{m}$. dose every other day. The first afebrile day and the first day without parasitemia are counted from the day on which the treatment was begun, that day being day 0 . The subjects treated with pentaquine at $60 \mathrm{mgm}$. daily concurrently with quinine who have not relapsed have been observed for varying periods of time, as follows: moderately infected -eight for five or six months, 11 for 15 or 16 months and six for 14 months or more; severely infected - nine for 21 to 24 months, one for 16 months, four for 14 months or more. A longer period of observation is unlikely to change these results materially because in 107 cases which relapsed after treatment with 8-aminoquinolines and quinine over 90 per cent relapsed within six weeks. The 75 controls (4) were treated with one or more of the following drugs: $\mathrm{SN}-4,095, \mathrm{SN}-8,617, \mathrm{SN}-10,275, \mathrm{SN}-11,437$ (metachloridine), SN-7,618 (chloroquine), quinine, quinacrine (atabrine), and paludrine (1).

relapsed. This relapse rate of 95 per cent is comparable to the 98 per cent relapse rate obtained when similar severely infected subjects were treated with suppressive drugs.

Dosages of pentaquine of $60 \mathrm{mgm}$. of the base a day, alone, with paludrine, or with quinine were effective in modifying the relapse rate of the severely infected patients. Given alone, pentaquine therapy decreased the relapse rate to two relapses for the four subjects; given with paludrine, it did not lower the relapse rate further; given with quinine, however, pentaquine reduced the relapse rate of the severely infected subjects to three relapses out of 17 subjects treated. Therefore, the concurrent administration of quinine with pentaquine was clearly more efficacious than pentaquine alone or the combination of pentaquine with paludrine. The quinine-pentaquine regime at the 
dosage of $60 \mathrm{mgm}$. a day of the latter drug resulted in a reduction of the relapse rate from 98 per cent to 18 per cent in subjects with severe infections.

In subjects treated in primary attacks after $e x$ traordinarily heavy inocula, however, the 100 per cent relapse rate obtained after suppressive drugs was unchanged. Four subjects were treated with pentaquine at $60 \mathrm{mgm}$. and quinine; all relapsed.

\section{Concentration of pentaquine in plasma}

It will be observed that the mean concentrations of drug in the plasma varied widely (Table I). The individual variations were so great that the group means have little significance. The increase in plasma concentrations attained when quinine was concurrently administered with pentaquine may not be significant because of the wide scatter. There was only a slight positive correlation between dosage of pentaquine and plasma pentaquine concentration on regimes in which quinine was concurrently administered. A striking increase in plasma concentration of pentaquine when paludrine was concurrently administered, on the other hand, was uniformly obtained.

The therapeutic effect of pentaquine, however, was not enhanced by the concurrent administration of paludrine in spite of the increased plasma concentrations. Furthermore, in any one dosage regime there did not appear to be a correlation between the individual plasma concentrations and the therapeutic results.

\section{Toxicity}

Ninety-nine white subjects were treated with pentaquine alone or in combination with paludrine or quinine in doses not exceeding $60 \mathrm{mgm}$. base a day. Symptoms elicited were qualitatively like those produced by pamaquin, but less severe than would occur with equal doses of the latter drug.

Toxicity at 15 to $45 \mathrm{mgm}$. of base per day. Except for the production of small amounts of methemoglobin no significant symptoms occurred in the

TABLE II

The toxicity of pentaquine given for 14 days in doses not exceeding $60 \mathrm{mgm}$. of the base daily

\begin{tabular}{|c|c|c|c|c|c|c|c|c|c|}
\hline \multirow{3}{*}{$\begin{array}{l}\text { Daily dose } \\
\text { of SN-13,276 } \\
\text { (base) }\end{array}$} & \multirow{3}{*}{$\begin{array}{l}\text { Number } \\
\text { of cases }\end{array}$} & \multicolumn{3}{|c|}{ Symptoms } & \multicolumn{4}{|c|}{ Laboratory observations } & \multirow{3}{*}{$\begin{array}{c}\text { Approximate } \\
\text { daily dose of } \\
\text { pamaquin } \\
\text { which produces } \\
\text { comparable } \\
\text { toxicity }\end{array}$} \\
\hline & & \multicolumn{2}{|c|}{$\begin{array}{l}\text { Abdominal } \\
\text { discomfort }\end{array}$} & \multirow{2}{*}{$\begin{array}{c}\begin{array}{c}\text { Anorexia } \\
\text { or nausea }\end{array} \\
\text { Moderate }\end{array}$} & \multirow{2}{*}{$\begin{array}{c}\text { Fever } \\
\text { over } \\
100.6^{\circ} \\
\text { rectal }\end{array}$} & \multirow{2}{*}{$\begin{array}{c}\text { Leucocytosis } \\
\text { (over } \\
12,000 \\
\text { per cu. } \mathrm{mm} \text {.) }\end{array}$} & \multicolumn{2}{|c|}{$\begin{array}{l}\text { Methemoglobin } \\
\text { formed* }\end{array}$} & \\
\hline & & Moderate & Severe & & & & Range & Mean & \\
\hline $\begin{array}{c}\text { mgm. } \\
15 \\
\text { with } \\
\text { quinine }\end{array}$ & $\begin{array}{r}\text { no. } \\
5\end{array}$ & no. & no. & no. & $\begin{array}{c}\text { no. } \\
1\end{array}$ & $\begin{array}{r}\text { no. } \\
1\end{array}$ & $\begin{array}{l}\text { per cent of } \\
2.1-3.3\end{array}$ & $\begin{array}{l}\text { tal } h g b . \\
2.6\end{array}$ & $\begin{array}{l}\text { mgm. } \\
\text { Less than } 15\end{array}$ \\
\hline $\begin{array}{c}30 \\
30 \\
\text { with } \\
\text { quinine }\end{array}$ & $\begin{array}{r}5 \\
10\end{array}$ & 1 & & & & 2 & $\begin{array}{l}2.7-3.8 \\
1.0-4.9\end{array}$ & $\begin{array}{l}3.2 \\
2.8\end{array}$ & $\begin{array}{l}15 \\
15\end{array}$ \\
\hline $\begin{array}{c}45 \\
\text { with } \\
\text { quinine }\end{array}$ & 5 & 1 & & & & 1 & $2.1-3.3$ & 2.6 & 15 \\
\hline 60 & 5 & 1 & & & & & $3.6-7.0$ & 4.5 & 30 \\
\hline $\begin{array}{c}60 \\
\text { with } \\
\text { paludrine }\end{array}$ & 5 & 1 & 2 & & & & $2.8-8.5$ & 4.5 & 30 \\
\hline $\begin{array}{c}60 \\
\text { with } \\
\text { quinine }\end{array}$ & 64 & 27 & 1 & 3 & 3 & 14 & $0.8-10.2$ & 3.9 & 30 \\
\hline
\end{tabular}

* Methemoglobin values are the average of the last five days of treatment. The average value obtained on analysis of the blood of 196 normal subjects was 1.8 per cent of total hemoglobin. The standard deviation was 1.10 and the standard error of the mean 0.08 . 
25 subjects receiving doses of $45 \mathrm{mgm}$. or less daily (Table II). One patient had transient unexplained fever on the ninth day of treatment. Three patients had transient mild leukocytosis. The degree of methemoglobinemia and the symptomatology were similar to that produced by a daily dose of $15 \mathrm{mgm}$. of pamaquin base.

Toxicity at $60 \mathrm{mgm}$. of base per day. With doses of $60 \mathrm{mgm}$. of pentaquine base, toxic symptoms occurred. In no instance among 74 subjects were the symptoms severe enough to warrant discontinuance of the drug (Tables II and III).

Abdominal discomfort was the outstanding symptom. Twenty-nine subjects complained of pain, either mild but persistent or moderately severe and transient. Fifteen others noted mild, transient abdominal discomfort. In one subject pain was severe. The distress was usually epigastric, sometimes radiating into the retrosternal area. It bore no apparent relationship to any bodily function and was unrelieved by food. In order not to mask the symptomatology, analgesics were withheld. Occasionally epigastric tenderness was an accompanying finding.

Mild anorexia was a common occurrence. In a few subjects, it was severe enough to result in a small weight loss which was, however, quickly regained when the therapeutic course was completed.

A few volunteers complained of transient weakness, headache, or diarrhea, but these symptoms were not severe. In three subjects, fever on the fourth, seventh, or tenth day was observed.

TABLE III

The therapeutic and toxic effects of pentaquine administered at a dose of 60 mgm. of the base daily, with quinine for 14 days

\begin{tabular}{|c|c|c|c|c|c|c|c|c|c|}
\hline \multirow{2}{*}{$\begin{array}{c}\text { Case } \\
\text { num- } \\
\text { ber }\end{array}$} & \multirow[b]{2}{*}{$\begin{array}{l}\text { Severity of } \\
\text { infection }\end{array}$} & \multirow{2}{*}{$\begin{array}{c}\text { Mean } \\
\text { concen- } \\
\text { tration } \\
\text { of } \\
\text { SN-13,276 } \\
\text { in plasma }\end{array}$} & \multirow[b]{2}{*}{ Result } & \multicolumn{2}{|c|}{ Symptoms } & \multicolumn{3}{|c|}{ Laboratory observations } & \multirow[b]{2}{*}{ Comment* } \\
\hline & & & & $\begin{array}{c}\text { Abdom- } \\
\text { inal } \\
\text { discom- } \\
\text { fort* }\end{array}$ & $\begin{array}{c}\text { Ano- } \\
\text { rexia } \\
\text { and } \\
\text { nau- } \\
\text { sea* }\end{array}$ & $\begin{array}{l}\text { White } \\
\text { blood } \\
\text { count* }\end{array}$ & $\begin{array}{c}\text { Met- } \\
\text { hemo- } \\
\text { globin } \\
\text { formed }\end{array}$ & $\begin{array}{c}\text { Change } \\
\text { of } \\
\text { hemo- } \\
\text { globin } \ddagger\end{array}$ & \\
\hline $\begin{array}{r}1 \\
2 \\
3 \\
4 \\
5 \\
6 \\
7 \\
8 \\
9 \\
9 \\
10 \\
11 \\
12 \\
13 \\
14 \\
15 \\
16 \\
17\end{array}$ & $\begin{array}{c}\text { No } \\
\text { clinical } \\
\text { malaria } \\
\text { (treated } \\
\text { during } \\
\text { latency) }\end{array}$ & $\begin{array}{c}\text { gamma/L. } \\
47 \\
103 \\
66 \\
63 \\
54 \\
39 \\
107 \\
117 \\
42 \\
42 \\
39 \\
20 \\
49 \\
35 \\
158 \\
58 \\
40 \\
25\end{array}$ & $\begin{array}{l}\text { Cases } 1 \text { through } 17 \\
\text { were treated af ter } \\
\text { several months of } \\
\text { spontaneous or in- } \\
\text { duced latency. Many } \\
\text { had had several re- } \\
\text { lapses and had devel- } \\
\text { oped a considerable } \\
\text { degree of immunity; } \\
\text { observations on these } \\
\text { patients are of value } \\
\text { only for toxicity. } \\
\text { None have relapsed } \\
\text { during many months } \\
\text { of observation. }\end{array}$ & $\begin{array}{c}0 \\
++ \\
0 \\
++ \\
++ \\
++ \\
+ \\
++ \\
0 \\
++ \\
++ \\
++ \\
++ \\
0 \\
++ \\
0 \\
0\end{array}$ & $\begin{array}{c}0 \\
++ \\
0 \\
0 \\
0 \\
0 \\
+ \\
+ \\
+ \\
+ \\
0 \\
+ \\
0 \\
+ \\
0 \\
+ \\
0 \\
0\end{array}$ & $\begin{array}{c}\text { per } \\
\text { cu. mm. } \\
N \\
18,500 \\
18 \\
N \\
N \\
N \\
12,000 \\
13,700 \\
13,700 \\
14,400 \\
N \\
N \\
13,100 \\
N \\
N \\
13,100 \\
= \\
-\end{array}$ & $\begin{array}{c}\text { per cent } \\
\text { of total } \\
\text { hemo- } \\
\text { globin } \\
2.7 \\
6.1 \\
6.1 \\
2.9 \\
5.9 \\
2.7 \\
6.6 \\
9.8 \\
3.5 \\
4.1 \\
2.1 \\
3.1 \\
3.8 \\
8.4 \\
3.0 \\
3.9 \\
1.4\end{array}$ & $\begin{array}{c}\text { grams } \\
\text { per } \\
100 \\
c c . \\
+0.6 \\
-0.1 \\
-0.4 \\
-0.1 \\
-0.9 \\
-1.2 \\
-0.3 \\
-2.1 \\
-1.1 \\
-1.3 \\
-1.1 \\
-1.6 \\
-1.3 \\
-1.6 \\
-1.5 \\
-1.0 \\
-1.3\end{array}$ & $\begin{array}{l}\text { Pain in chest }++ \\
\text { Headache }+; \text { fever } 5 \text { th } \\
\text { and } 6 \text { th days } \\
\text { Headache }+ \\
\text { Diarrhea }+ \\
\text { Headache }+ \\
\text { Diarrhea }+\end{array}$ \\
\hline $\begin{array}{l}18 \\
19 \\
20 \\
21 \\
22 \\
23 \\
24 \\
25 \\
26 \\
27 \\
28 \\
29 \\
30\end{array}$ & $\begin{array}{l}\text { Moderate } \\
\text { (long } \\
\text { prepattent } \\
\text { or } \\
\text { preceding } \\
\text { latent } \\
\text { period) }\end{array}$ & $\begin{array}{r}114 \\
49 \\
64 \\
45 \\
37 \\
41 \\
28 \\
63 \\
43 \\
165 \\
\\
45 \\
96 \\
80\end{array}$ & $\begin{array}{l}\text { No relapse in } 6 \text { mos. } \\
\text { No relapse in } 6 \text { mos. } \\
\text { No relapse in } 6 \text { mos. } \\
\text { No relapse in } 5 \text { mos. } \\
\text { No relapse in } 5 \text { mos. } \\
\text { No relapse in } 5 \text { mos. } \\
\text { No relapse in } 5 \text { mos. } \\
\text { No relapse in } 5 \text { mos. } \\
\text { No relapse in } 5 \text { mos. } \\
\text { No relapse in } 4 \text { mos. } \\
\text { No relapse in } 4 \text { mos. } \\
\text { No relapse in } 4 \text { mos. } \\
\text { No relapse in } 4 \text { mos. }\end{array}$ & $\begin{array}{l}+ \\
++ \\
++ \\
0 \\
+ \\
0 \\
0 \\
++ \\
0 \\
+ \\
0 \\
0 \\
+\end{array}$ & $\begin{array}{l}0 \\
0 \\
0 \\
0 \\
+ \\
+ \\
0 \\
0 \\
0 \\
0 \\
0 \\
0 \\
0\end{array}$ & $\begin{array}{c}\mathbf{N} \\
\mathbf{N} \\
\mathbf{N} \\
\mathbf{N} \\
\mathbf{N} \\
\mathbf{N} \\
16,200 \\
\mathbf{N} \\
3,600 \\
15,500 \\
\mathbf{N} \\
\mathbf{N} \\
-\end{array}$ & $\begin{array}{l}5.7 \\
5.2 \\
5.0 \\
2.9 \\
2.5 \\
2.7 \\
1.4 \\
4.3 \\
2.9 \\
5.9 \\
4.8 \\
8.3 \\
3.6\end{array}$ & $\begin{array}{l}-1.4 \\
-0.4 \\
-0.5 \\
-0.7 \\
-0.5 \\
-0.1 \\
+0.3 \\
-0.5 \\
-0.3 \\
-0.6 \\
+0.4 \\
+1.0 \\
+1.0\end{array}$ & $\begin{array}{l}\text { Fever on } 7 \text { th day } \\
\text { Diarrhea }{ }^{+}++ \\
\text {Chest pain }++\end{array}$ \\
\hline
\end{tabular}


TABLE III-Continued

\begin{tabular}{|c|c|c|c|c|c|c|c|c|c|}
\hline \multirow[b]{2}{*}{$\begin{array}{l}\text { Case } \\
\text { num- } \\
\text { ber }\end{array}$} & \multirow[b]{2}{*}{$\begin{array}{c}\text { Severity of } \\
\text { infection }\end{array}$} & \multirow{2}{*}{$\begin{array}{c}\text { Mean } \\
\text { concen- } \\
\text { tration } \\
\text { of } \\
\text { SN-13,276 } \\
\text { in plasma }\end{array}$} & \multirow[b]{2}{*}{ Result } & \multicolumn{2}{|c|}{ Symptoms } & \multicolumn{3}{|c|}{ Laboratory observations } & \multirow[b]{2}{*}{ Comment* } \\
\hline & & & & $\begin{array}{c}\text { Abdom- } \\
\text { inal } \\
\text { discom- } \\
\text { fort* }\end{array}$ & $\begin{array}{l}\text { Ano- } \\
\text { rexia } \\
\text { and } \\
\text { nau- } \\
\text { sea* }\end{array}$ & $\begin{array}{l}\text { White } \\
\text { blood } \\
\text { count* }\end{array}$ & $\begin{array}{c}\text { Met- } \\
\text { hemo- } \\
\text { globin } \\
\text { formed } \dagger\end{array}$ & $\begin{array}{c}\text { Change } \\
\text { of } \\
\text { hemo- } \\
\text { globin } \ddagger\end{array}$ & \\
\hline $\begin{array}{l}31 \\
32 \\
33 \\
34 \\
35 \\
36 \\
37 \\
38 \\
39 \\
40 \\
41 \\
42 \\
43\end{array}$ & $\begin{array}{c}\text { Moderate } \\
\text { (long } \\
\text { prepatent } \\
\text { or } \\
\text { preceding } \\
\text { latent } \\
\text { period) } \\
\text { continued }\end{array}$ & \begin{tabular}{|c} 
gamma/L. \\
39 \\
39 \\
82 \\
37 \\
74 \\
44 \\
37 \\
70 \\
50 \\
27 \\
54 \\
68 \\
30
\end{tabular} & $\begin{array}{l}\text { No relapse in } 4 \text { mos. } \\
\text { No relapse in } 4 \text { mos. } \\
\text { No relapse in } 4 \text { mos. } \\
\text { No relapse in } 3 \frac{1}{3} \text { mos. } \\
\text { No relapse in } 3 \frac{13}{\text { mos. }} \\
\text { No relapse in } 3 \frac{1}{3} \text { mos. } \\
\text { No relapse in } 2 \frac{1}{2} \text { mos. } \\
\text { No relapse in } 2 \frac{13}{3} \text { mos. } \\
\text { No relapse in } 2 \frac{3}{2} \text { mos. } \\
\text { No relapse in } 2 \text { mos. } \\
\text { No relapse in } 2 \text { mos. } \\
\text { No relapse in } 2 \frac{1}{3} \text { mos. } \\
\text { Relapsed in } 22 \text { days }\end{array}$ & $\begin{array}{l}0 \\
+ \\
0 \\
0 \\
++ \\
++ \\
++ \\
+ \\
0 \\
0 \\
+ \\
++ \\
0\end{array}$ & $\begin{array}{c}+ \\
0 \\
0 \\
++ \\
0 \\
0 \\
0 \\
0 \\
0 \\
0 \\
0 \\
0 \\
0\end{array}$ & $\begin{array}{c}\text { per } \\
c u . m m . \\
-\bar{m} \\
12,300 \\
N \\
N \\
N \\
N \\
N \\
N \\
N \\
15,600 \\
N \\
N \\
N\end{array}$ & \begin{tabular}{|c} 
per cent \\
of total \\
hemo- \\
globin \\
3.1 \\
2.5 \\
2.1 \\
3.1 \\
4.6 \\
2.2 \\
3.1 \\
1.6 \\
2.8 \\
1.3 \\
3.8 \\
3.9 \\
2.8
\end{tabular} & $\begin{array}{c}\text { grams } \\
\text { per } \\
100 \\
c c . \\
-0.5 \\
-0.5 \\
-1.1 \\
+0.1 \\
-0.6 \\
-0.3 \\
-0.9 \\
-0.6 \\
-0.7 \\
-0.9 \\
-1.5 \\
-1.3 \\
-1.5\end{array}$ & Headache + \\
\hline $\begin{array}{l}44 \\
45 \\
46 \\
47 \\
48 \\
49 \\
50 \\
51 \\
52 \\
53 \\
54 \\
55 \\
56 \\
57 \\
58 \\
59 \\
60\end{array}$ & $\begin{array}{l}\text { Severe } \\
\text { (short } \\
\text { prepatent } \\
\text { or } \\
\text { preceding } \\
\text { latent } \\
\text { period) }\end{array}$ & $\begin{array}{r}56 \\
55 \\
68 \\
87 \\
57 \\
130 \\
59 \\
68 \\
\\
90 \\
54 \\
54 \\
196 \\
64 \\
43 \\
34 \\
26 \\
27\end{array}$ & $\begin{array}{l}\text { No relapse in } 12 \text { mos. } \\
\text { No relapse in } 12 \text { mos. } \\
\text { No relapse in } 12 \text { mos. } \\
\text { No relapse in } 12 \text { mos. } \\
\text { No relapse in } 11 \text { mos. } \\
\text { No relapse in } 9 \text { mos. } \\
\text { No relapse in } 9 \text { mos. } \\
\text { No relapse in } 9 \text { mos. } \\
\text { No relapse in } 9 \text { mos. } \\
\text { No relapse in } 4 \text { mos. } \\
\text { Relapsed in } 70 \text { days } \\
\text { No relapse in } 2 \frac{1}{3} \text { mos. } \\
\text { No relapse in } 2 \frac{1}{3} \text { mos. } \\
\text { Relapsed in } 45 \text { days } \\
\text { Relapsed in } 54 \text { days } \\
\text { No relapse in } 2 \text { mos. } \\
\text { No relapse in } 2 \text { mos. }\end{array}$ & $\begin{array}{c}++ \\
0 \\
0 \\
++ \\
++ \\
++ \\
++ \\
++ \\
0 \\
++ \\
+ \\
+++ \\
++ \\
0 \\
++ \\
++ \\
0\end{array}$ & $\begin{array}{c}0 \\
0 \\
0 \\
0 \\
+ \\
0 \\
0 \\
0 \\
0 \\
+ \\
0 \\
++ \\
+ \\
0 \\
0 \\
+ \\
0\end{array}$ & $\begin{array}{c}\mathbf{N} \\
\mathbf{N} \\
\mathbf{N} \\
\mathbf{N} \\
\mathbf{N} \\
\mathbf{N} \\
\mathbf{N} \\
12,000 \\
\mathbf{N} \\
13,600 \\
\mathbf{N} \\
\mathbf{N} \\
12,800 \\
\mathbf{N} \\
\mathbf{N} \\
\mathbf{N}\end{array}$ & $\begin{array}{r}3.9 \\
4.6 \\
9.9 \\
10.2 \\
3.3 \\
6.4 \\
4.3 \\
3.4 \\
5.5 \\
2.9 \\
0.8 \\
2.7 \\
1.2 \\
1.0 \\
1.1 \\
4.1 \\
1.3\end{array}$ & $\begin{array}{r}+0.5 \\
-1.0 \\
-2.0 \\
-1.6 \\
+0.3 \\
-0.7 \\
-1.5 \\
0.0 \\
-0.1 \\
-0.6 \\
-0.9 \\
-0.2 \\
-1.1 \\
-1.1 \\
+0.1 \\
-0.8 \\
+0.2\end{array}$ & $\begin{array}{l}\text { Headache }+ \\
\text { Headache }+ \\
\text { Diarrhea }+ \\
\text { Headache }+ \\
\text { Diarrhea }+ \text {; weak- } \\
\text { ness }+ \\
\text { Fever on 4th day } \\
\text { Headache }+ \\
\text { Weakness }++\end{array}$ \\
\hline $\begin{array}{l}61 \\
62 \\
63 \\
64\end{array}$ & \begin{tabular}{l}
\multicolumn{1}{c}{ Massive } \\
(intracutane- \\
ous inocula- \\
tion of glands \\
of $45-75$ mos- \\
quitoes or 80 \\
bites)
\end{tabular} & $\begin{array}{l}54 \\
38 \\
68 \\
93\end{array}$ & $\begin{array}{l}\text { Relapsed in } 87 \text { days } \\
\text { Relapsed in } 19 \text { days } \\
\text { Relapsed in } 43 \text { days } \\
\text { Relapsed in } 44 \text { days }\end{array}$ & $\begin{array}{c}0 \\
++ \\
0 \\
+\end{array}$ & $\begin{array}{l}0 \\
0 \\
0 \\
0\end{array}$ & $\begin{array}{l}\mathbf{N} \\
\mathbf{N} \\
\mathbf{N} \\
\mathbf{N}\end{array}$ & $\begin{array}{l}2.4 \\
2.9 \\
5.4 \\
4.1\end{array}$ & $\begin{array}{l}-1.4 \\
-0.1 \\
-1.7 \\
-0.3\end{array}$ & $\begin{array}{l}\text { Afebrile relapse followed } \\
\text { by spontaneous latency }\end{array}$ \\
\hline
\end{tabular}

* The clinical impression of the severity of the toxic symptom is graded on the basis of + to ++++ . $N$ represents a normal leucocyte count.

$\dagger$ Methemoglobin values are the average of the findings on the last five days of treatment. The average obtained on analysis of the blood of 196 normal subjects was 1.8 per cent of total hemoglobin. The standard deviation was 1.10 and the standard error of the mean 0.08 .

$\ddagger$ The change of hemoglobin was the difference between the average of the hemoglobin values of the first five days of treatment and the average of hemoglobin estimations on the last and four subsequent days.

Electrocardiograms revealed a diminution in the height of the $T$ waves in some or all of the leads. $\mathrm{T}_{3}$ sometimes became inverted; in other cases an inverted $T_{3}$ became upright. In only a few instances was the $T$ wave amplitude reduced below normal height. Serial electrocardiograms in such cases showed a return to the configuration of the control tracing after the course of treatment was completed. Urinary abnormalities were not observed; the urinary output remained normal.

There was an elevation of the leucocyte count above 12,000 per cu. $\mathrm{mm}$. in 14 subjects. Three subjects had a leucopenia as low as $\mathbf{3 0 0 0}$ to $\mathbf{3 6 0 0}$. However, in all instances of either leucocytosis or leucopenia, differential leucocyte counts were normal, and the abnormalities were in most in- 
stances unconfirmed by serial leucocyte estimations.

In the presence of clinical malaria, it is difficult to evaluate a slight fall in hemoglobin. However, in this series, 16 of the 17 subjects receiving pentaquine at $60 \mathrm{mgm}$. of pentaquine base a day with quinine for 14 days, at a time when they had neither fever nor parasitemia, demonstrated a small decline in hemoglobin. The initial and terminal hemoglobin values were the average of five daily determinations. The loss amounted to an average of $1.0 \mathrm{gram}$ per $100 \mathrm{cc}$. of blood (6.7 per cent of the initial hemoglobin) with a range of +0.6 to -2.1 gram per $100 \mathrm{cc}$. Although the loss was small, it exceeded one gram in 11 of the 17 subjects. No subject developed acute hemolytic anemia.

The production of methemoglobin was common and, in effect, further reduced the amount of available oxygen-carrying hemoglobin. In the 17 subjects without malaria, methemoglobinemia averaged 0.66 gram per $100 \mathrm{cc}$. ( 4.4 per cent of the total hemoglobin) during the last five days of treatment. If this be added to the 1.0 gram per cent of hemoglobin lost, the total diminution in oxygen-carrying hemoglobin amounted to 1.66 grams per $100 \mathrm{cc}$. of blood or 11.1 per cent of the total hemoglobin.

Of the 74 subjects treated with $60 \mathrm{mgm}$. of the base daily, only nine failed to show methemoglobinemia in excess of the mean value ( 1.8 per cent of the hemoglobin) obtained in normal blood by this method. In ten subjects, it exceeded 6 per cent of the total hemoglobin, above which level cyanosis was clinically evident. In the remaining 55, methemoglobin was produced but not in amounts great enough to be detected on inspection.

Comparison with pamaquin. The average per cent of hemoglobin converted to methemoglobin bears a rough relationship to the clinical symptomatology and permits quantitative comparison with the various pamaquin regimes. The toxicity of pentaquine at 15 to $45 \mathrm{mgm}$. of base per day was equivalent to no more than that of $15 \mathrm{mgm}$. of pamaquin base. At $60 \mathrm{mgm}$. of pentaquine base, either alone or in conjunction with paludrine or quinine, the toxicity was approximately equivalent to that of $30 \mathrm{mgm}$. of pamaquin base $(67 \mathrm{mgm}$. of pamaquine naphthoate).
Effect of concurrent administration of quinine on toxicity. The toxicity of pentaquine in this series of 99 cases was not increased by the concomitant administration of quinine, as it is in experimental animals. In fact, average methemoglobin values were slightly lower for the groups receiving quinine (Table II). However, the number of men treated without quinine was too small to permit final evaluation.

\section{DISCUSSION}

A clinical trial of pentaquine in 99 white subjects infected with vivax malaria has proved this drug to be a promising antimalarial agent. In doses which were well tolerated, the drug caused a marked reduction in the relapse rate when administered in conjunction with quinine. In a group of moderately infected patients the relapse rate was reduced from 67 per cent to 4 per cent and in severely infected patients, from 98 per cent to 18 per cent. In subjects with massive inoculations it did not prevent relapse (Figure 2).

The effectiveness of pentaquine at $60 \mathrm{mgm}$. of the base in preventing relapse was enhanced by the concurrent administration of quinine. This finding is paralleled by observations previously made ( 8 to 11 ) with pamaquin and quinine. It is of interest that in the severely infected group in which quinine alone has a negligible effect and pentaquine and pamaquin alone only a moderate effect in preventing relapse, the concurrent administration of quinine with either of these drugs is highly effective. Quinine appears, therefore, to potentiate the effect of these two 8-aminoquinolines. Synergism between pentaquine and paludrine, however, could not be demonstrated in severely infected subjects.

Pentaquine has clear therapeutic superiority over the usual suppressive antimalarials. It shares this superiority with pamaquin which also has been demonstrated ( 8 to 11 ) to have curative properties in vivax malaria. With both drugs the limiting factor is the inherent toxicity of the therapeutic agent. Sixty mgm. of pentaquine base have an effect on the relapse rate approaching that of $90 \mathrm{mgm}$. of pamaquin base. Ninety mgm. of pamaquin, however, cause severe toxicity, making it impractical for clinical use. Sixty $\mathrm{mgm}$. of pentaquine, on the other hand, causes toxicity sim- 


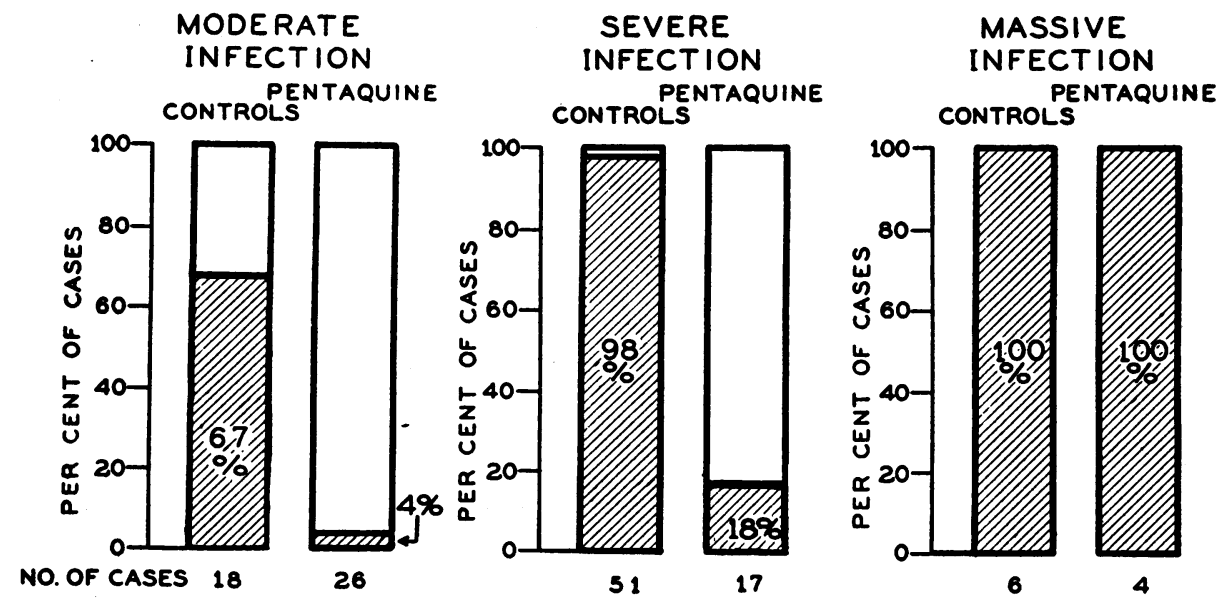

Fig. 2. The Effect of Pentaquine on the Relapse Rate of Mosquito-induced Vivax Malaria (Chesson Strain)

Pentaquine was given for two weeks at $60 \mathrm{mgm}$. of the base per day. Quinine was concurrently administered. Control subjects were treated with a variety of suppressive drugs. Per cent figures indicate relapse rate.

ilar to that produced by $30 \mathrm{mgm}$. of pamaquin, a dosage well tolerated in most white patients.

Pentaquine is not, however, an innocuous drug. Studies of its effect at 120 and $180 \mathrm{mgm}$. of base daily have shown serious toxicity including, in addition to more severe symptoms of the type described at $60 \mathrm{mgm}$. base, severe weakness, prostration, anoxia, postural hypotension and syncope persisting for months after the termination of therapy (12). The potential occurrence of severe symptoms at lower doses must be borne in mind when less robust or smaller individuals are treated.

The absence of acute hemolytic anemia in this series may be due in part to sampling and in part to limiting studies to white subjects. With pamaquin, hemolytic anemia occurs rarely in whites, and more commonly in colored races (2). Pentaquine has in fact precipitated acute hemolytic anemia in a white individual $(2,13)$.

Pentaquine may prove clinically useful in doses less than $60 \mathrm{mgm}$. a day. Although pamaquin must be given at $90 \mathrm{mgm}$. of base to cure the severely infected non-immune individual $(10,11)$, doses as low as $\mathbf{2 7} \mathrm{mgm}$. of base a day lowered the relapse rate to a striking degree in returned service men who had been on prolonged suppressive therapy (14). By analogy it may be that pentaquine will be found useful in doses considerably lower than those required for the severely infected volunteers studied during this investigation. At doses lower than $60 \mathrm{mgm}$. we have found negligible toxicity, but the possibility of acute hemolytic anemia must not be overlooked. We believe hospitalization throughout the treatment course for the purpose of observation (as well as to ensure the four-hourly administration of the drug) to be essential in view of our present limited knowledge of this new therapeutic agent.

\section{CONCLUSIONS}

The therapeutic effect of pentaquine ( $\mathrm{SN}-13$,276) has been studied in acute attacks of Chesson Southwest Pacific strain of vivax malaria, under standardized conditions.

Pentaquine is effective in reducing the relapse rate of vivax infections. Its curative properties are enhanced by the concurrent administration of quinine. A daily dose of $60 \mathrm{mgm}$. of pentaquine base ( $80 \mathrm{mgm}$. of the monophosphate) and 2 grams of quinine sulfate, administered concurrently in divided doses every four hours for 14 days, reduced the relapse rate in severely infected patients from 98 per cent to 18 per cent. In moderate infections, the relapse rate was reduced from 67 per cent to 4 per cent. With massive infections, however, combined pentaquine-quinine therapy failed to prevent relapse in the four subjects studied. 
Some evidence suggests that considerably lower doses of pentaquine may effect a radical reduction of relapse rate of vivax malaria in individuals who stop suppressive therapy upon return to non-endemic areas after long residence in hyper-endemic regions.

Pentaquine should only be administered under close medical supervision, preferably during hospitalization. The daily dose of $60 \mathrm{mgm}$. base should not be exceeded. This dose has approximately the same toxicity as $30 \mathrm{mgm}$. of pamaquin (base) or $67 \mathrm{mgm}$. of its naphthoate salt. The toxicity of pentaquine is too great to warrant its use in prophylaxis or prolonged suppression of malaria. The safe therapeutic dose for children and the toxicity of the drug in negroes and individuals of mixed racial extraction is at present undetermined.

\section{BIBLIOGRAPHY}

1. Wiselogle, F. Y., editor, A Survey of Antimalarial Drugs, 1941-1945. Edwards Brothers, Inc., Ann Arbor, 1946.

2. Loeb, R. F., Clark, W. M., Coatney, G. R., Coggeshall, L. T., Dieuaide, F. R., Dochez, A. R., Hakansson, E. G., Marshall, E. K., Jr., Marvel, C. S., McCoy, O. R., Sapero, J. J., Sebrell, W. H., Shannon, J. A., and Carden, G. A., Jr., Activity of a new antimalarial agent, pentaquine (SN13,276). Statement approved by the Board for Coordination of Malarial Studies. J. A. M. A., 1946, 132, 321.

3. Alving, A. S., Craige, B., Jr., Pullman, T. N., Whorton, C. M., Jones, R., Jr., and Eichelberger, L., Procedures used at Stateville Penitentiary for the testing of potential antimalarial agents. J. Clin. Invest., 1948, 27, Suppl., 2.

4. Craige, B., Jr., Alving, A. S., Jones, R., Jr., Whorton, C. M., Pullman, T. N., and Eichelberger, L.,
The Chesson strain of Plasmodium vivax malaria. II. Relationship between prepatent period, latent period and relapse rate. J. Infect. Dis., 1947, 80, 228.

5. Jones, R., Jr., Craige, B., Jr., Alving, A. S., Whorton, C. M., Pullman, T. N., and Eichelberger, L., A study of the prophylactic effectiveness of several 8-aminoquinolines in sporozoite-induced vivax malaria (Chesson strain). J. Clin. Invest., 1948, 27, Suppl., 6.

6. Brodie, B. B., Udenfriend, S., and Taggart, J. V., The estimation of basic organic compounds in biological material. IV. Estimation by coupling with diazonium salts. J. Biol. Chem., 1947, 168, 327.

7. Wendel, W. B., Personal communication.

8. Sinton, J. A., and Bird, W., Studies in malaria with special reference to treatment: plasmoquine in treatment of malaria. Indian J. Med. Research, 1928, 16, 159.

9. Fourth General Report of the Malaria Commission, Bull. of the Health Organization of the League of Nations, 1937, 6, 895.

10. Berliner, R. W., Taggart, J. V., Zubrod, C. G., Welch, W. J., Earle, D. P., Jr., and Shannon, J. A., Pamaquin: 1. Curative antimalarial activity in vivax malaria. Fed. Proc., 1946, 5, 165.

11. Craige, B., Jr., Jones, R., Jr., Whorton, C. M., Pullman, T. N., Alving, A. S., and Eichelberger, L., Clinical standardization of pamaquin in mosquitoinduced vivax malaria, Chesson strain. Am. J. Trop. Med., 1947, 27, 309.

12. Craige, B., Jr., Jones, R., Jr., Eichelberger, L., Alving, A. S., Pullman, T. N., and Whorton, C. M., The toxicity of large doses of pentaquine (SN13,276) a new antimalarial drug. J. Clin. Invest., 1948, 27, Suppl., 17.

13. Coatney, G. R., et al., Personal communication.

14. Most, H., Kane, C., Lavietes, P. H., London, I. M., Schroeder, E. F., and Hayman, J. M., Combined quinine-plasmochin treatment of vivax malaria; effect on relapse rate. Am. J. Med. Sci., 1946, 212,550 . 